\title{
Kinerja Rumah Sakit Swasta dengan Pembayaran INA- CBGs di Era Jaminan Kesehatan Nasional: Casemix, Casemix Index, Hospital Base Rate
}

\author{
Performance of Private Hospitals with INA-CBGs Payments in the Era of \\ National Health Insurance: Casemix, Casemix Index, Basic Hospital Rates
}

\author{
Atik Nurwahyuni, ${ }^{1}$ Ery Setiawan, ${ }^{2}$ \\ ${ }^{1}$ Departemen Administrasi dan Kebijakan Kesehatan, Fakultas Kesehatan Masyarakat, Universitas Indonesia \\ ${ }^{2}$ Pusat Kajian Ekonomi dan Kebijakan Kesehatan, Fakultas Kesehatan Masyarakat, Universitas Indonesia
}

\begin{abstract}
Korespondensi: Atik Nurwahyuni
e-mail:atikn.akk@gmail.com

\section{Abstrak}

Pembayaran ke rumah sakit yang sebelumnya fee for service, pada era JKN diselenggarakan melalui pola DRG atau INA-CBGs. Rumah sakit swasta harus memonitor kinerjanya menggunakan indikator yang lazim digunakan dalam sistem pembayaran DRG yaitu casemix, casemix index dan Hospital base rate. Kajian ini bertujuan untuk menganalisis kinerja rumah sakit swasta meliputi casemix, casemix index dan hospital base rate. Studi cross sectional ini dilakukan dengan sampel 7 RS yang dipilih secara purposif mewakili RS swasta kelas B, C, dan D yang tersebar di 6 provinsi. Casemix dan CMI RS sangat dipengaruhi oleh kapasitas RS sehingga RS kelas B memiliki casemix dan CMI lebih tinggi dari RS kelas $C$ dan D. Terdapat fenomena CMI di RS kelas C lebih kecil dari kelas D yang kemungkinan disebabkan oleh akurasi koding. Kelengkapan dan ketepatan pengkodean diagnosis dan prosedur sangat berdampak pada besaran casemix dan CMI RS. Hampir semua RS memiliki HBR di atas HBR Nasional kecuali RSC3. Dapat dipastikan RSC3 mendapatkan profit dari implementasi INA-CBGs. Rumah sakit sebaiknya memonitor casemix, CMI dan HBR secara berkala. Kementerian Kesehatan diharapkan mempublikasikan cost weight dan HBR Nasional INA-CBGs serta besaran rata-rata casemix dan CMI menurut kelas RS agar dapat digunakan sebagai benchmark oleh RS.
\end{abstract}

Kata kunci: INA-CBGs, casemix, casemix index, hospital base rate

\begin{abstract}
Private hospitals must monitor their performance using indicators commonly used in DRG payment systems: casemix, casemix index and hospital base rate. This study aims to analyze the performance of private hospitals including casemix, casemix index and hospital base rate. This cross sectional study was conducted with a sample of 7 hospitals selected purposively representing private hospital type B, C, and D in 6 provinces. Casemix and CMI RS are strongly influenced by the hospital capacity, which the hospitals class $B$ have higher casemix and CMI than class $\mathrm{C}$ and $\mathrm{D}$ hospitals. There is a phenomenon, $\mathrm{CMI}$ in class $\mathrm{C}$ hospitals smaller than class $\mathrm{D}$ which is probably caused by coding accuracy. The completeness and accuracy of diagnosis and procedures coding predominating affect the casemix and CMI. Almost all hospitals have HBR which are higher than National HBR except RSC3. It definitely will trigger profit from the implementation of INA-CBGs. Hospitals should monitor casemix, CMI and HBR regularly. The Ministry of Health is expected to publish the Cost Weight and National HBR as well as the average of casemix and CMI according to class of hospital, for a benchmark by hospitals.

Keywords: INA-CBGs, casemix, casemix index, Hospital base rate

\section{Pendahuluan}

Diselenggarakannya program JKN membawa perubahan yang cukup signifikan khususnya

pada pembayaran fasilitas kesehatan terutama rumah sakit. Pola pembayaran ke rumah sakit yang sebelumnya berbasis fee for service, pada era JKN diselenggarakan melalui pola
\end{abstract}


diagnosis related group (DRG) yang di Indonesia dikenal dengan INA-CBGs (Indonesian Case Based Groups). Saat ini, sebagian besar pasien di rumah sakit swasta merupakan pasien $\mathrm{JKN}$, bahkan proporsinya ada yang mencapai $90 \%$ sehingga $80-90 \%$ pendapatan rumah sakit swasta sangat ditentukan oleh pembayaran INA-CBG (BPJS-Kesehatan, 2015). Dalam praktiknya, tantangan yang dihadapi oleh rumah sakit swasta berbeda dengan rumah sakit pemerintah. Hal yang paling mendasar adalah rumah sakit swasta harus mendanai sendiri semua biaya yang dikeluarkan termasuk biaya investasi dan biaya operasional. Kepesertan JKN yang terus meningkat dan ditargetkan mencakup seluruh penduduk akan menjadi tantangan tersendiri khususnya bagi RS swasta. Manajemen RS harus mampu beradaptasi sehingga mampu bertahan dan berkembang di era JKN melalui monitoring kinerja secara berkala dan penyusunan strategi yang diperlukan.

Selama ini, rumah sakit telah berupaya untuk memonitor kinerjanya di bawah pembayaran INA-CBGs dengan menggunakan beberapa indikator misal jumlah kasus per grup, tingkat keparahan (severity level), status pulang, lama hari rawat, pembandingan besaran tarif INA-CBGs dan tarif rumah sakit per kasus dan lain-lain. Selain indikator kinerja di atas, terdapat tiga indikator lainnya yang lazim digunakan dalam sistem pembayaran DRG yaitu casemix, casemix index dan Hospital base rate (Murray, 2017)

Dalam pembayaran INA-CBGs, kasus yang memiliki tingkat keparahan lebih tinggi akan menerima pembayaran lebih tinggi, begitu pula sebaliknya. Ukuran keparahan sebuah kasus dalam CBGs direfleksikan dengan cost weight karena pada umumnya keparahan sebuah kasus akan sangat mempengaruhi sumber daya atau biaya yang dibutuhkan selama perawatan (O'Dougherty, et al., 2009). Cost weight adalah angka yang menunjukkan bobot biaya antar CBG, semakin tinggi biaya perawatan sebuah CBG maka akan semakin besar pula cost weightnya, semakin tinggi tingkat keparahan suatu penyakit maka akan semakin besar pula cost weight-nya (Fattore \& Torbica, 2006). Angka cost weight ini dihitung pada skala nasional sehingga berlaku untuk semua rumah sakit baik pemerintah maupun swasta, untuk semua kelas rumah sakit baik kelas A, B, C dan $\mathrm{D}$ di semua wilayah/regional. Dalam pembayaran INA-CBGs, jumlah kasus yang dilayani oleh rumah sakit belum bisa secara akurat menjelaskan aktivitas sebuah rumah sakit. Casemix menunjukkan volume aktivitas rumah sakit secara lebih nyata karena mempertimbangkan jumlah kunjungan dan keparahan penyakit yang diderita pasien (O'Dougherty, et al., 2009).

Casemix dihitung dengan menjumlahkan perkalian antara jumlah kasus per CBG dan cost weight (Schreyogg, et al., 2006). Dua rumah sakit yang memiliki jumlah kasus yang sama akan sangat mungkin memiliki casemix yang berbeda karena kompleksitas kasus yang ditanganinya berbeda. Semakin banyak jumlah kasus yang ditangani rumah sakit maka semakin besar casemix nya, semakin tinggi severity level kasus yang ditangani rumah sakit maka semakin besar casemix nya. Angka casemix ini secara langsung akan menunjukkan besaran pembayaran yang di terima rumah sakit. Semakin besar casemix sebuah rumah sakit maka akan semakin besar pula pembayaran yang akan diterima.

Casemix index (CMI) lazim digu-nakan oleh RS untuk memonitor kinerjanya karena mencerminkan rata-rata keparahan penyakit yang ditangani oleh RS (Mendez, et al., 2014). Casemix index mencerminkan ratarata terbobot cost weight yang ditangani oleh rumah sakit. Semakin tinggi CMI maka semakin tinggi pula rata-rata keparahan pasien yang ditangani oleh RS. Umumnya RS yang fasilitasnya lengkap dan canggih akan memiliki CMI yang lebih tinggi. Selain nilai casemix dan CMI, indicator kinerja lainnya adalah Hospital Based rate (HBR). 
Nilai ini dihitung dengan menggunakan dua variable yaitu dengan membagi Total Biaya RS dengan casemix RS. Angka ini sangat krusial karena angka ini langsung memberikan informasi apakah rumah sakit mengalami surplus atau kerugian dengan pembayaran DRG atau CBG. Bila base rate rumah sakit lebih kecil dari base rate nasional yang digunakan oleh pemerintah untuk menetapkan tarif maka rumah sakit akan surplus, tapi bila base rate rumah sakit lebih besar daripada base rate nasional maka dapat dipastikan rumah sakit menderita kerugian (Vogl, 2012). Dengan membandingkan casemix, casemix index, dan HBR pada rumah sakit yang memiliki kapasitas yang sama maka evaluasi kinerja pelayanan dan efisiensi RS dapat dilakukan. Tiga indikator di atas sangat penting artinya bagi rumah sakit, namun belum pernah digunakan oleh rumah sakit karena keterbatasan pengetahuan serta keterbatasan data yaitu tidak dipublikasikannya angka cost weight oleh Kementerian Kesehatan. Kajian ini bertujuan untuk menganalisis kinerja rumah sakit swasta meliputi casemix, casemix index dan Hospital base rate.

\section{Metode Penelitian}

Rancangan studi ini adalah cross-sectional, dimana peneliti hanya mengamati suatu fenomena dalam satu periode tertentu tanpa melakukan intervensi terhadap subjek yang diteliti. Populasi studi ini adalah seluruh Rumah Sakit Swasta di Indonesia. Pemilihan sampel rumah sakit dilakukan secara purposif mewakili RS kelas B, C, dan D yang tersebar di Indonesia barat, tengah, timur menurut ketersediaan dan kelengkapan data serta kesediaan pihak manajemen Rumah Sakit memberikan semua data yang dibutuhkan. Sampel berjumlah 7 rumah sakit dengan rincian 2 RS Kelas B, 3 RS Kelas C dan 2 RS Kelas D di 6 provinsi yaitu Provinsi Jawa Tengah, Jawa Barat, Sumatera Utara, Sulawesi Selatan, Sulawesi Utara dan Nusa Tenggara Timur. Data yang digunaka dalam studi ini adalah data klaim RS, jumlah kunjungan rawat jalan dan rawat inap di RS, dan laporan keuangan tahun 2014-2016.

Beberapa rumah sakit mulai menjadi provider JKN pada tahun 2015 dan 2016. Untuk penghitungan casemix, casemix index, dan Hospital base rate dibutuhkan data cost weight, namun data ini tidak dipublikasikan oleh Kementerian Kesehatan. Dalam kajian ini, cost weight dan Hospital base rate nasional diprediksi dengan menggunakan data tarif INA-CBGs yang berlaku pada tahun 2014-2016 (PMK No.59 tahun 2014) dan data klaim Jamkesmas 2012 menggunakan rumus rata-rata biaya perawatan 1 CBG dibagi dengan rata-rata biaya perawatan semua CBG.

Rata-rata biaya perawatan 1 CBG direpresentasikan oleh tarif INA-CBGs sedangkan rata-rata perawatan semua $\mathrm{CBG}$ diperoleh dari penjumlahan perkalian jumlah kasus per CBG selama setahun dengan tarif INA-CBGs kemudian dibagi dengan total kasus. Penghitungan casemix menggunakan rumus $\Sigma$ (cost weight X Jumlah Kasus), sedangkan casemix index dihitung dengan membagi casemix dengan total kasus. Hospital base rated di RS dihitung dengan membagi total biaya dengan casemix. Hospital base rate yang dihitung adalah HBR rawat jalan dan rawat inap, oleh karenanya harus dipisahkan dan dihitung terlebih dahulu total biaya rawat inap dan total biaya rawat jalan. Pemisahan dan penghitungan total biaya rawat inap dan rawat jalan dari total biaya rumah sakit menggunakan proporsi pendapatan rawat inap dan rawat jalan.Dalam penghitungan HBR rawat jalan, diperlukan 2 data yaitu total biaya RS untuk rawat jalan dan casemix rawat jalan. Total biaya rawat jalan ini termasuk biaya konsultasi, obat, penunjang medik, tindakan dan biaya lainnya. Terdapat kendala bagi RS untuk memisahkan biaya rawat jalan bagi pasien umum dan pasien JKN, oleh karenanya penghitungan HBR rawat jalan dilakukan sacara agregat dan tidak dipisahkan menurut jenis pasien. Untuk itu, total biaya rawat jalan yang dihitung adalah untuk semua pasien, begitu pula casemix nya. Penghitungan casemix 
rawat jalan semua pasien dilakukan dengan mengalikan total kasus rawat jalan di RS dengan casemix index pasien JKN, dengan asumsi tingkat keparahan pasien JKN sama

\section{HASIL}

\section{Karakteristik rumah sakit}

Tidak semua rumah sakit yang masuk dalam sampel bekerjasama dengan Badan Penyelenggara Jaminan Sosial Kesehatan (BPJS Kesehatan) mulai tahun 2014. RSC3 bekerjasama dengan BPJS Kesehatan mulai tahun 2016, sedangkan RSD1 dan RSD2 mulai bekerjasama tahun 2015. Jumlah tempat tidur bervariasi antar rumah sakit sesuai dengan kelas RS nya dengan rentang dengan pasien umum. Penghitungan HBR rawat inap dilakukan dengan menggunakan metodologi yang sama.

54 hingga 397 tempat tidur. Tempat tidur terbanyak dimiliki oleh RSB1 sedangkan RSD2 memiliki tempat tidur paling sedikit. Bed Occupancy Ratio (BOR) relative rendah berkisar 38\% hingga $78 \%$ dan cenderung fluktuatif tiap tahunnya. Pada tahun 2016 BOR terendah dimiliki oleh RSC3 sedangkan BOR tertinggi dimiliki oleh RSC1. Proporsi pendapatan RS dari JKN sangat bervariasi antar RS dan di sebagian RS cenderung terus meningkat hingga 2016 seperti terlihat pada

Tabel 1 Karakteristik Rumah Sakit Tahun 2014-2016

\begin{tabular}{cccccccccc}
\hline \multirow{2}{*}{ Rumah Sakit } & \multicolumn{3}{c}{ Jumlah Tempat Tidur } & & BOR & & \multicolumn{2}{c}{$\begin{array}{c}\text { Proporsi Pendapatan } \\
\text { RS dari JKN }\end{array}$} \\
\cline { 2 - 10 } & $\mathbf{2 0 1 4}$ & $\mathbf{2 0 1 5}$ & $\mathbf{2 0 1 6}$ & $\mathbf{2 0 1 4}$ & $\mathbf{2 0 1 5}$ & $\mathbf{2 0 1 6}$ & $\mathbf{2 0 1 4}$ & $\mathbf{2 0 1 5}$ & $\mathbf{2 0 1 6}$ \\
\hline RS Kelas B & & & & & & & & & \\
RSB1 & 396 & 397 & 397 & $69 \%$ & $63 \%$ & $66 \%$ & $18 \%$ & $6 \%$ & $18 \%$ \\
RSB2 & 345 & 345 & 345 & $71 \%$ & $71 \%$ & $69 \%$ & $11 \%$ & $28 \%$ & $35 \%$ \\
RS Kelas C & & & & & & & & & \\
RSC1 & 155 & 180 & 220 & $78 \%$ & $78 \%$ & $78 \%$ & $71 \%$ & $73 \%$ & $39 \%$ \\
RSC2 & 172 & 172 & 166 & $38 \%$ & $39 \%$ & $67 \%$ & $22 \%$ & $39 \%$ & $37 \%$ \\
RSC3 & 224 & 215 & 245 & $44 \%$ & $75 \%$ & $52 \%$ & & & $59 \%$ \\
RS Kelas D & & & & & & & & & \\
RSD1 & 122 & 122 & 99 & $70 \%$ & $70 \%$ & $58 \%$ & & $61 \%$ & $40 \%$ \\
RSD2 & 54 & 54 & 54 & $67 \%$ & $60 \%$ & $61 \%$ & & $7 \%$ & $58 \%$ \\
\hline
\end{tabular}

Casemix, Casemix index, dan Hospital base rate Rawat Jalan

Rumah sakit kelas B memiliki jumlah kasus paling banyak hingga mencapai 103.746 kasus pada tahun 2016, sedangkan RS kelas D memiliki jumlah kasus paling sedikit yaitu 1.748 kasus. Pada RS kelas B di tahun 2015, RSB1 memiliki casemix rawat jalan JKN lebih besar dari RSB2 namun berubah pada tahun 2016. Di antara RS kelas C, RSC3 memiliki casemix rawat jalan JKN paling tinggi dibanding RS lainnya. Sedangkan pada RS Kelas D, RSD2 memiliki casemix rawat jalan JKN yang lebih besar dibandingkan dengan RSD1. Casemix index mencerminkan rata-rata tingkat keparahan kasus yang dirawat oleh RS dan sangat berkaitan dengan kapasitas RS. Pada Tabel 2 terlihat bahwa rumah sakit kelas B memiliki CMI yang jauh lebih tinggi dibandingkan RS kelas C dan D. Walaupun pada kelas yang sama, RSB1 memiliki CMI rawat jalan yang jauh lebih tinggi dibandingkan dengan RSB2 yaitu 1,4472. Pada RS kelas C, RSC3 memiliki CMI paling tinggi $(0,9924)$. Sementara pada RS kelas D, RSD2 memiliki CMI yang lebih tinggi dibandingkan dengan RSD1. Hal yang menarik adalah RSC3 (RS kelas C) memiliki CMI lebih besar dari RSB2 dan RSC2 memiliki CMI lebih rendah dari pada RS kelas D. 
Tabel 2 Jumlah Kasus, Casemix dan Casemix Index Rawat Jalan JKN di Rumah Sakit Tahun 2014-2016

\begin{tabular}{|c|c|c|c|c|c|c|c|c|c|}
\hline \multirow{2}{*}{ Rumah Sakit } & \multicolumn{3}{|c|}{ Jumlah Kasus JKN } & \multicolumn{3}{|c|}{ Casemix JKN } & \multicolumn{3}{|c|}{ Casemix Index } \\
\hline & 2014 & 2015 & 2016 & 2014 & 2015 & 2016 & 2014 & 2015 & 2016 \\
\hline \multicolumn{10}{|l|}{ RS Kelas B } \\
\hline RSB1 & 40.818 & 55.737 & 47.090 & 65.006 & 81.522 & 68.148 & 1,5926 & 1,4626 & 1,4472 \\
\hline RSB2 & 25.287 & 60.853 & 103.746 & 26.076 & 53.118 & 84.447 & 1,0312 & 0,8729 & 0,8140 \\
\hline \multicolumn{10}{|l|}{ RS Kelas C } \\
\hline RSC1 & 11.275 & 10.653 & 11.159 & 8.661 & 7.958 & 8.227 & 0,7682 & 0,7471 & 0,7373 \\
\hline $\mathrm{RSC2}$ & 11.309 & 23.291 & 21.321 & 6.993 & 12.146 & 9.782 & 0,6183 & 0,5215 & 0,4588 \\
\hline RSC3 & & & 17.165 & & & 17.034 & & & 0,9924 \\
\hline \multicolumn{10}{|l|}{ RS Kelas D } \\
\hline RSD1 & & 3 & 1.748 & & 2 & 1.342 & & 0,6683 & 0,7678 \\
\hline RSD2 & & 442 & 5.587 & & 319 & 4.540 & & 0,7217 & 0,8127 \\
\hline
\end{tabular}

Tabel 2 hanya memberikan informasi tentang kasus JKN sementara Tabel 3 memberikan penjelasan terkait total kasus yang ada di rumah sakit baik pasien JKN, pasien umum dan pasien lainnya. Informasi total kasus di rumah sakit digunakan untuk menghitung Hospital base rate di masingmasing RS.

Jumlah kasus rawat jalan cenderung terus meningkat tiap tahunnya di semua RS.
Rumah Sakit kelas B memiliki jumlah kasus dan casemix rawat jalan paling banyak dibandingkan dengan RS kelas C dan D. Pada RS kelas B, RSB1 memiliki casemix jauh lebih tinggi dibandingkan dengan RSB2. Pada RS kelas C, RSC3 memiliki casemix paling tinggi sedangkan pada RS kelas D, RSD2 memiliki casemix yang jauh lebih tinggi dari RSD1.

Tabel 3 Jumlah Kasus, Casemix dan Hospital Base Rate Rawat Jalan di Rumah Sakit Tahun 2014-2016

\begin{tabular}{|c|c|c|c|c|c|c|c|c|c|}
\hline \multirow{2}{*}{$\begin{array}{c}\text { Rumah } \\
\text { Sakit }\end{array}$} & \multicolumn{3}{|c|}{ Jumlah Kasus RS } & \multicolumn{3}{|c|}{ Casemix RS } & \multicolumn{3}{|c|}{ Hospital Base Rate (Rp) } \\
\hline & 2014 & 2015 & 2016 & 2014 & 2015 & 2016 & 2014 & 2015 & 2016 \\
\hline \multicolumn{10}{|l|}{ RS Kelas B } \\
\hline RSB1 & 251.477 & 242.737 & 253.226 & 400.496 & 355.030 & 366.465 & 228.823 & 279.199 & 289.655 \\
\hline RSB2 & 204.488 & 217.454 & 231.242 & 210.865 & 189.814 & 188.226 & 191.735 & 251.553 & 292.578 \\
\hline \multicolumn{10}{|l|}{ RS Kelas C } \\
\hline RSC1 & 13.567 & 11.150 & 19.681 & 10.422 & 8.330 & 14.510 & 257.814 & 349.944 & 234.477 \\
\hline RSC2 & 31.336 & 41.486 & 52.679 & 19.377 & 21.634 & 24.169 & 251.545 & 339.905 & 262.508 \\
\hline RSC3 & 63.680 & 45.655 & 50.606 & & & 50.220 & & & 149.140 \\
\hline \multicolumn{10}{|l|}{ RS Kelas D } \\
\hline RSD1 & & 9.651 & 11.047 & & 6.450 & 8.482 & & 48.361 & 43.110 \\
\hline RSD2 & & 27.712 & 26.798 & & 20.000 & 21.778 & & 66.691 & 63.464 \\
\hline
\end{tabular}


Hospital base rate RS kelas B cenderung lebih tinggi dibandingkan dengan RS kelas C dan D. Pada tahun 2016, RSB2 memiliki HBR paling tinggi dibandingkan RS lainnya sebesar Rp. 292.578. Diantara RS kelas C, RSC2 memiliki HBR paling tinggi yaitu Rp. 262.508, sementara di RS kelas D RSD1 memiliki HBR lebih rendah dibandingkan dengan RSD2 yaitu sebesar Rp. 43.110.

\section{Casemix, Casemix index, dan Hospital base} rate Rawat Inap

Jumlah dan jenis kasus rawat inap JKN yang ditangani oleh rumah sakit sangat bervariasi. Rumah sakit kelas B memiliki jumlah kasus paling banyak, berkisar antara 8.131 sampai 10.401 kasus pada tahun 2016, sedangkan RS kelas D memiliki jumlah kasus paling sedikit yaitu 1.821 dan 3.730 kasus. Casemix di RS sangat fluktuatif mengikuti jumlah kasusnya. Pada RS kelas B di tahun 2016, RSB2 memiliki casemix rawat inap JKN lebih besar dari RSB1. Di antara RS kelas C, RSC3 memiliki casemix rawat inap JKN paling tinggi dibanding RS lainnya. Sedangkan pada RS Kelas D, RSD1 memiliki casemix rawat inap JKN yang lebih besar dibandingkan dengan RSD2.

Pada Tabel 4 terlihat bahwa rumah sakit kelas B memiliki CMI yang jauh lebih tinggi dibandingkan RS kelas C dan D. Walaupun pada kelas yang sama, RSB2 $(1,2866)$ memiliki CMI rawat inap yang jauh lebih tinggi dibandingkan dengan RSB1 (1,1673). Pada RS kelas C, RSC1 $(0,8795)$ memiliki CMI paling tinggi dan RSC3 $(0,8390)$ memiliki CMI yang paling rendah. Sementara pada RS kelas D, RSD1 $(1,0399)$ memiliki CMI yang lebih tinggi dibandingkan dengan RSD2 (0,8570). Hal yang menarik adalah RSD1 (RS kelas D) memiliki CMI lebih besar daripada RS kelas C.

Tabel 4 Jumlah Kasus, Casemix dan Casemix Index Rawat Inap JKN di Rumah Sakit Tahun 2014-2016

\begin{tabular}{cccccccccc}
\hline \multirow{2}{*}{ Rumah Sakit } & \multicolumn{3}{c}{ Jumlah Kasus JKN } & \multicolumn{3}{c}{ Casemix JKN } & \multicolumn{3}{c}{ Casemix Index } \\
\cline { 2 - 9 } & $\mathbf{2 0 1 4}$ & $\mathbf{2 0 1 5}$ & $\mathbf{2 0 1 6}$ & $\mathbf{2 0 1 4}$ & $\mathbf{2 0 1 5}$ & $\mathbf{2 0 1 6}$ & $\mathbf{2 0 1 4}$ & $\mathbf{2 0 1 5}$ & $\mathbf{2 0 1 6}$ \\
\hline RS Kelas B & & & & & & & & & \\
RSB1 & 6.063 & 9.069 & 8.131 & 8.232 & 11.008 & 9.491 & 1,3578 & 1,2138 & 1,1673 \\
RSB2 & 2.356 & 7.784 & 10.401 & 3.671 & 10.323 & 13.382 & 1,5583 & 1,3262 & 1,2866 \\
RS Kelas C & & & & & & & & & \\
RSC1 & 10.077 & 9.459 & 6.428 & 11.023 & 8.825 & 5.654 & 1,0939 & 0,9330 & 0,8795 \\
RSC2 & & 2.691 & 3.685 & & 2.476 & 3.233 & & 0,9202 & 0,8773 \\
RSC3 & & & 7.440 & & & 6.242 & & & 0,8390 \\
RS Kelas D & & & & & & & & & \\
RSD1 & & 4.990 & 3.730 & & 5.590 & 3.879 & & 1,1202 & 1,0399 \\
RSD2 & & & 1.821 & & & 1.561 & & & 0,8570 \\
\hline
\end{tabular}

Tabel 5 memberikan informasi total kasus rawat inap yang ada di rumah sakit baik pasien JKN, pasien umum dan pasien lainnya yang digunakan untuk menghitung Hospital base rate di RS. Jumlah kasus rawat inap terus meningkat tiap tahunnya hampir di semua RS. Mirip dengan rawat jalan, Rumah Sakit kelas B memiliki jumlah kasus dan casemix rawat inap paling banyak dibandingkan dengan RS kelas C dan D. Pada RS kelas B, RSB1 memiliki casemix lebih tinggi dibandingkan dengan RSB2. Sedangkan pada RS kelas C, RSC1 memiliki casemix paling tinggi dibandingkan RSC2 dan RSC3. Pada RS kelas D, RSD1 memiliki casemix yang jauh lebih tinggi dari RSD2 
Tabel 5 Jumlah Kasus, Casemix dan Hospital Base Rate Rawat Inap di Rumah Sakit Tahun 2014-2016

\begin{tabular}{|c|c|c|c|c|c|c|c|c|c|}
\hline \multirow{2}{*}{ Rumah Sakit } & \multicolumn{3}{|c|}{ Jumlah Kasus RS } & \multicolumn{3}{|c|}{ Casemix RS } & \multicolumn{3}{|c|}{ Hospital Base Rate } \\
\hline & 2014 & 2015 & 2016 & 2014 & 2015 & 2016 & 2014 & 2015 & 2016 \\
\hline \multicolumn{10}{|l|}{ RS Kelas B } \\
\hline RSB1 & 27.546 & 28.323 & 29.099 & 37.401 & 33.436 & 33.967 & 5.104 .845 & 5.954 .485 & 6.201 .327 \\
\hline RSB2 & 23.213 & 24.354 & 24.771 & 36.173 & 32.298 & 31.871 & 4.327 .635 & 5.382 .256 & 5.706 .181 \\
\hline \multicolumn{10}{|l|}{ RS Kelas C } \\
\hline RSC1 & 11.364 & 11.629 & 14.070 & 12.431 & 10.850 & 12.375 & 4.353 .482 & 4.000 .637 & 4.093 .839 \\
\hline $\mathrm{RSC2}$ & & 7.165 & 8.799 & & 6.593 & 7.719 & & 3.343 .847 & 3.952 .159 \\
\hline RSC3 & & & 10.458 & & & 8.775 & & & 3.077 .522 \\
\hline \multicolumn{10}{|l|}{ RS Kelas D } \\
\hline RSD1 & & 8.672 & 7.381 & & 9.714 & 7.676 & & 1.262 .707 & 2.947 .333 \\
\hline RSD2 & & & 3.621 & & & 3.103 & & & 3.039 .503 \\
\hline
\end{tabular}

Hospital base rate RS kelas B cenderung lebih tinggi dibandingkan dengan RS kelas C dan D. Pada tahun 2016, RSB1 memiliki HBR paling tinggi dibandingkan RS lainnya sebesar Rp. 6.201.327. Diantara RS kelas C, RSC1 memiliki HBR paling tinggi yaitu Rp. 4.093.839, sementara di RS kelas D RSD1 memiliki HBR lebih rendah dibandingkan dengan RSD2 yaitu sebesar Rp. 2.947.333.

\section{Pembahasan}

\section{Karakteristik Rumah Sakit}

Bed occupancy rate merupakan indikator yang sangat penting untuk menilai kinerja pelayanan dan kinerja keuangan. Angka BOR yang ideal adalah 80\%-85\% (Setyawan \& Supriyanto, 2019). Rendahnya BOR memberikan gambaran kurang optimalnya pemanfaatan sumber daya RS terutama barang investasinya. Keputusan rumah sakit menyediakan sejumlah tempat tidur akan diikuti dengan beberapa konsekuensi langsung yaitu penyediaan lahan, bangunan, alat medik, alat non medik dan juga sumber daya manusia terutama perawat. Bila semua sumber daya tersebut sudah disiapkan namun BOR rendah sehingga hanya sebagian kecil tempat tidur yang terpakai maka banyak sekali investasi yang tidak termanfaatkan dengan baik. Dengan kata lain bahwa output yang ada tidak mampu mencapai kapasitas rumah sakit sehingga tidak efisien (Irwandy, 2019). BOR yang rendah akan menyebabkan tingginya Hospital base rate rawat inap. Peningkatan BOR cukup signifikan yang dialami oleh RSC2 pada tahun 2016 berdampak pada penurunan HBR rawat inap yang juga signifikan.Tidak semua rumah sakit swasta bersedia bekerjasama dengan BPJS Kesehatan di awal implementasi JKN. Mereka cenderung mengamati dulu kelebihan dan kekurangan program JKN serta dampak positif dan negatifnya bagi RS swasta, oleh karena itulah ada beberapa RS yang memulai kerjasama dengan BPJS Kesehatan pada tahun 2015 atau 2016 (BPJS_Kesehatan, 2014). Kebijakan diijinkannya dokter praktek di 3 RS menyebabkan mobilitas dokter di rumah sakit swasta tinggi (Kemenkes, 2011). Bergabungnya atau keluarnya seorang dokter dengan spesialisasi atau sub spesialisasi tertentu akan memberikan dampak langsung terhadap jumlah kunjungan dan jenis kasus pasien sehingga mempengaruhi BOR dan CMI. Banyak RS yang hanya membuka poli tertentu saja bagi peserta JKN. Bahkan banyak RS pula yang memberlakukan kuota maksimum jumlah pasien JKN per harinya. Perilaku ini terlihat dari besar kecilnya proporsi pendapatan RS dari JKN. 


\section{Casemix, Casemix index, dan Hospital base rate Rawat Jalan}

Jumlah kasus akan memberikan dampak secara langsung pada besaran angka casemix. Semakin besar jumlah kasus maka akan semakin besar pula casemix nya (Francis, et al., 2001). Umumnya, kapasitas rumah sakit akan mempengaruhi secara langsung terhadap besaran casemix (OECD, 2013). Rumah sakit dengan kelas kapasitas atau kelas yang sama, seharusnya memiliki besaran casemix dan casemix index yang hampir sama (Murray, 2017). Pada tahun 2016 di RS kelas B, RSB2 memiliki casemix JKN lebih besar dari RSB1 karena terjadi peningkatan jumlah kasus yang signifikan. Namun demikian, CMI RSB1 jauh lebih tinggi dibandingkan RSB2. Hal ini dikarenakan RSB1 banyak menangani kasus hemodialysis yang memiliki cost weight cukup tinggi sedangkan RSB2 banyak menangani Penyakit Kronis Kecil Lain-Lain yang cost weightnya tidak terlalu tinggi. RSB1 lebih berhasil mengontrol biaya rawat jalan dibandingkan RSB2 sehingga tidak terjadi kenaikan HBR yang signifikan. Walaupun demikian, HBR RSB1 masih lebih tinggi daripada HBR Nasional. Hospital base rate Nasional Rawat Jalan Kelas B adalah Rp. 231.526. Rumah sakit cenderung kurang efisien ketika melayani pasien umum karena pembayaran masih menggunakan fee for service. Masih tingginya proporsi pasien umum menyebabkan total biaya RS besar, hal inilah yang menyebabkan HBR RS masih lebih tinggi dari HBR Nasional.

HBR Nasional Rawat Jalan Kelas C adalah Rp. 219.938. Pada RS kelas C, hanya RSC3 yang sangat efisien dan memiliki HBR di bawah HBR Nasional. Rendahnya HBR RSC3 dikarenakan tingginya jumlah kasus rawat jalan, tingginya CMI dan terkontrolnya biaya rawat jalan di RS. Tingginya CMI di RSC3 karena melayani hemodialysis, sedangkan RS lainnya tidak membuka pelayanan ini. RSC2 memiliki CMI yang sangat kecil bahkan di bawah CMI RS kelas D karena proporsi terbesar kasus rawat jalan yang ditanganinya adalah medical check up (hingga mencapai 90\%) yang memiliki cost weight sangat kecil $(0,4276)$. Terdapat kemungkinan terjadi ketidaklengkapan dan ketidaktepatan pengkodean diagnosis dan prosedur di RSC2 sehingga menyebabkan undercode (Sutherland \& Botz, 2006). Semua RS kelas D memiliki HBR yang sangat kecil dibawah HBR Nasional Rawat Jalan Kelas D sebesar Rp. 209.644. Kecilnya HBR di RS kelas D dikarenakan keberhasilan RS mengontrol biaya rawat jalan.

Casemix, Casemix index, dan Hospital base rate Rawat Inap

Casemix dan CMI sangat dipengaruhi oleh kapasitas RS, oleh karenanya sangat wajar bila RS kelas B memiliki casemix dan CMI yang lebih besar dari RS kelas C dan D. Casemix index cenderung turun tiap tahunnya hampir di semua RS. Hal ini dikarenakan semakin ketatnya proses verifikasi klaim oleh BPJS terutama bagi kasus yang memiliki severity level 3.

Proporsi kasus severity level 2 dan severity level 3 di RSD1 lebih besar dibandingkan dengan RS kelas C. Hal inilah yang mengakibatkan RSD1 memiliki CMI yang lebih tinggi daripada CMI RS kelas C. Perlu analisis lebih lanjut terkait ketepatan dan kelengkapan pengkodean diagnosis dan prosedur baik di RS kelas C maupun RSD1. Terjadi kemungkinan undercode di RS kelas $\mathrm{C}$ atau overcode di RSD1.

Hospital base rate rawat inap di kelas B baik di RSB1 maupun di RSB2 jauh lebih besar dari HBR Nasional Rawat Inap Kelas B (Rp. 3.765.792). Masih tingginya proporsi pasien umum terutama di RSB1 menyebabkan total biaya rawat inap di RS besar, hal inilah yang menyebabkan HBR RS masih sangat tinggi hingga dua kali dari HBR Nasional. Besaran HBR Nasional Rawat Inap Kelas C adalah Rp. 3.064.867 sedangkan kelas D adalah Rp. 2.601.808. Pada RS kelas $\mathrm{C}$, hanya RSC3 yang memiliki HBR mendekati HBR Nasional karena memiliki total biaya rawat inap paling kecil sementara semua RS kelas D memiliki HBR di atas HBR Nasional. 


\section{KESIMPULAN DAN SARAN}

Casemix dan CMI RS sangat dipengaruhi oleh kapasitas RS sehingga RS kelas B memiliki casemix dan CMI lebih tinggi dari RS kelas $\mathrm{C}$ dan D. Terdapat fenomena CMI di RS kelas C lebih kecil dari kelas D yang kemungkinan disebabkan oleh akurasi koding. Kelengkapan dan ketepatan pengkodean diagnosis dan prosedur sangat berdampak pada besaran casemix dan CMI RS. Hampir semua RS memiliki HBR di atas HBR Nasional kecuali RSC3. Dapat dipastikan RSC3 mendapatkan profit dari implementasi INA-CBGs.

Rumah sakit sebaiknya memonitor casemix, CMI dan HBR secara berkala, membandingkannya dengan RS lain yang memiliki kapasitas sama dan memanfaatkan informasi tersebut untuk mengambil keputusan strategis dalam upaya peningkatan mutu dan efisiensi RS. Untuk itu Kementerian Kesehatan diharapkan mempublikasikan cost weight dan HBR Nasional INA-CBGs serta besaran rata-rata casemix dan CMI menurut kelas RS agar dapat digunakan sebagai benchmark oleh RS.

\section{DAFTAR PUSTAKA}

BPJS_Kesehatan, I., 2014. https://www.bpjskesehatan.go.id. [Online] Available at: https://www.bpjs-kesehatan.go.id/bpjs/ dmdocuments/bd905482f8126cfcdc03a92 42d175389.pdf [Accessed 10 December 2019].

BPJS-Kesehatan, 2015. Komitmen dan Kerja Keras Kunci Surplus RS Mardi Waluyo Kelola JKN Testimoni drg. Budiono Direktur RS Mardi Waluyo, Lampung.. [Online] Available at: https://bpjskesehatan.go.id/bpjs/index.php/post/read /2015/370/Komitmen-dan-Kerja-KerasKunci-Surplus-RS-Mardi-WaluyoKelola-JKN

Fattore, G. \& Torbica, A., 2006. Inpatient reimbursement system in Italy: How do tariffs relate to costs?. Health Care Manage Sci..
Francis, Mertens, I., Closon, M.-C. \& Hofdijk, J., 2001. Casemix: Global Views, Local Action Evolution in Twenty Countries. Amsterdam: IOS Press.

Irwandy, 2019. Efisiensi dan Produktifitas Rumah Sakit, Teori dan Aplikasi Pengukuran dengan Pendekatan Data Envelopment Analysis. Makasar: Social Politic Genius (SIGn).

Kemenkes, 2011. Peraturan Menteri Kesehatan Republik Indonesia Nomor 2052/Menkes/Per/X/2011 tentang Izin Praktik dan Pelaksanaan Praktik Kedokteran. s.l.:s.n.

Langenbrunner, J. C., Cashin, C. \& O'Dougherty, S., 2009. How To M An Introduction to Provider Payment System. In, Designing and implementing health care provider payment system: . In: s.l.:s.n.

Mendez, C. M., Harrington, D. W., Christen, P. \& Spellberg, B., 2014. Impact of Hospital Variables on Case Mix Index as a Marker of Disease Severity. Population Health Management, Volume Volume 17.

Murray, J. E., 2017. The CDI buzz about CMI: What your facility metrics mean. [Online] Available at: https://acdis.org /articles/guest-post-cdi-buzz-about-cmiwhat-your-facility-metrics-mean

O'Dougherty, S. et al., 2009. Case Based Hospital Payment System. In: J. C. Langenbrunner, C. Cashin \& S. O'Dougherty, eds. In Designing and implementing health care provider payment system: How To Manuals. . Wahington DC: s.n.

OECD, 2013. MANAGING HOSPITAL VOLUMES GERMANY AND EXPERIENCES FROM OECD COUNTRIES, s.l.: s.n.

Schreyogg, J., Stargardt, T., Tiemann, O. \& Busse, R., 2006. Methods to determine reimbursement rates for diagnosis related groups (DRG): A comparison of nine European countries.. Healt Care Manage Sci.. 
Setyawan, F. E. B. \& Supriyanto, S., 2019. Manajemen Rumah Sakit. Sidoarjo: Zifatama Jawara.

Sutherland, J. M. \& Botz, C. K., 2006. The effect of misclassification errors on case mix measurement. ELSEVIER Health Policy, Volume 79.

Vogl, M., 2012. Assessing DRG cost accounting with respect to resource allocation and tariff calculation: the case of Germany. Health Economics Review. 